\title{
Republic of Macedonia - Reform Priorities in Public Administration for a Pro- European Country
}

\author{
Suzana Mehmedi, Ph.D \\ Government of Republic of Macedonia - SIOFA \\ llir Mehmedi, Ph.D \\ University St Climent Ohridski - Faculty of Technical Sciences
}

\begin{abstract}
The problem of research is very current for several reasons. Namely, the dominant approach on the basis of which are based all have developed and established theories of European integration, developing modern theories of international relations is a realistic basis. Neo-functionalism, inter-guvernmentalism , neo-liberalism, institutionalism (in most of its variants) as the most developed branches of the theory of European integration, despite differences in their settings to keep the basic premise that states are rational, unitary actors, whose interest stems from the assessment of their position in the system of states. For our study caused a special interest model of constructivism using Habermas theory of communicative action according to which entities in mutual interaction is open to other arguments and their validity appreciate having regard to the outgoing reasons and norms on which they are based, thereby seeking consensus as a common goal. Apply to the European Union, this approach allows European institutions were perceived as a place of discussion to reach consensus on solving common problems, rather than just the arena for bargaining. Functional adaptation to the numerous petitions which sets the European Union, requires thorough and integrated activities in the economic, institutional, administrative and legislative spheres. This process should be understood as a continuous, painstaking and long process, not a single radical surgery. Republic of Macedonia, as countries aspiring for membership in the European family must meet the political and economic criteria and to adapt political institutions in the country with those of the European Union and their needs and requirements. The aim of this paper is to perceive the key features and trends in the politics of enlargement and to make a comparison between the policy of expansion applied in the process of accession Central and Eastern Europe and the policy of expansion in the process of stabilization and association, with special emphasis on the Republic of Macedonia. Of course, previously been necessary to develop theoretical and practical approach to the concept of policy integration, development and its major elements and modalities.
\end{abstract}

Keywords: European Union, integration, theoretical, practical, association

\section{Introduction}

The problem that this research tackles is very current for several reasons. Namely, the dominant approach, on the basis of which all European Integration theories have been established and developed, can be a realistic foundation for developing modern theories of international relations.

Neo-functionalism, inter-governmentalism, neo-liberalism, institutionalism (in most of its variations) as the most developed branches of the theory of European Integration, despite differences in their approaches, they all stand by their main premise: states are rational, unitary actors, whose interest stems from the assessment of their position in the system of states. For the purpose of our study, with a special interest in the model of constructivism, Habermas's theory of communicative action will be used, according to which, entities in mutual interaction are open to other arguments, and their validity is appreciated having into consideration the outgoing reasons and norms that form their basis, thereby seeking consensus as a common goal. When applied to the European Union, this approach allows European institutions to be perceived more as a space for discussion on how to reach consensus for solving common problems, rather than just an arena for bargaining. Functional 
adaptation to the numerous petitions, which the European Union sets, require thorough and integrated activities in the economic, institutional, administrative and legislative spheres. This process should be understood as a continuous, painstaking and long process, not a single radical surgery.

After the fall of communism in Eastern Europe, the process of integration of former communist states within the European Union was made possible to start. In the period from 1987 to 1996, 10 former communist states- Poland, the Czech Republic, Slovakia, Hungary, Bulgaria, Romania, Slovenia, Lithuania, Latvia and Estonia, as well as Turkey, Cyprus and Malta had already submitted an EU membership request. On the meeting of the European Council in Luxemburg, from the $12^{\text {th }}$ to the $13^{\text {th }}$ of December, 1997, the procedure for acceptance of these countries in the EU began. It was decided that "each candidate-country will progress by its own speed, according to the degree of its readiness". The EU, in the framework of its pre-accession strategies helped these candidate-countries adjust to its regulations via financial aid for development of institutions, infrastructure and the economy.

Under the influence of the influx of aspiring member countries, after the Cold War, the European Union, taking into consideration the already developed experience with international financial institutions, develops a system of measures that both aspiring member countries and the Union itself should fulfil so that they're entirely ready for their integration within the Union. This system of measures means a gradual fulfilment of conditions by the aspiring countries, which is supported and monitored with specific mechanisms by the Union's side.

The issue of this research paper is the theoretical and practical overview of the European Union's integration policy towards the countries that wish to become its members.

\section{Multi-Leveled Governance}

An alternative characteristic of EC's nature, which explicitly gave up on a larger part of its principles of inter-governmentalism, is that it represented a system of multi-leveled governance.

Initially developed in the study of the structural funds of the EC, this idea was later broadened in a fully-fledged theory. An earlier definition of Gary Marks ${ }^{1}$ spoke of:

the phenomenon of multi leveled governance, a system of continuous negotiation between governments on several territorial levelssupranational, national, regional and local.

The way in which the structural funds are distributed indicates the phase of the implementation of policies.

However, along with other writers, at a later stage he broadened the concept so that the phase of decision making is incorporated as well. ${ }^{2}$ While inter-governmentalism represented the process of European Integration which is ongoing according to the pace and level wanted by the governments of the member states, the ones who advocated for multi-leveled governance, even though accepted that integration incorporates inter-governmental bargaining, they considered that certain governments did not control the process.

Even if one accepts that the Council of Ministers dominates in terms of decision making, there are some limitations of the capacity of a country to control the results of such a joint decision making.

Supranational actors such as the Commission, the European Parliament, and the European Court of Justice, can be formed by the countries so that they are of help, but they do not remain under state control. Taking into consideration that there is a large number of member states, it is difficult for them to act together in terms of maintaining control; and since all institutional changes require a unanimous agreement, if the supranational institutions manage to increase their competences through legal and political means, it is very difficult to take away these competences from them via changes in the agreements.

\footnotetext{
${ }^{1}$ G. Marks, L. Hooghe, and K. Blank, 'European Integration since the 1980s: State-Centric Versus Multi-Level Governance', paper presented at the American Political Science Association Meeting, Chicago, August 31-September3, 1995.

${ }^{2}$ Moravcsik, A. (1993) 'Preferences and power in the European Community: a liberal intergovermentalist approach', Journal of Common Market Studies, vol.31, no.4, p.473-524
} 
Another reasons why the governments have difficulties to control the supranational institutions is because the state itself is not a unified actor. Moravcsik ${ }^{1}$ accepts this in his liberal inter-governmentalist stance as far as the process of defining national interests is concemed.

The concept of the EU as a multi-leveled governance system has a similar structure as the original neo-functionalist formulations. It can be considered as the newest manifestation of an approach of comprehending the EU that is contrary to the inter-governmentalist stance.

The debate between inter-governmentalism and multi-leveled governance is the last phase of a long lasting debate about the dynamics of European Integration, even though in its current manifestation it is more a debate about the nature of the European Union rather than a debate about the process of integration. The adopted approach in the other part goes back to the initial question and tries to identify the dynamic of integration, defined as a transfer of political competencies from a national to a supranational level.

The question inevitably focuses our attention on the position of the states, because the governments of the states should agree to the transfer of competencies. Hoffman²and Moravcsik were concrete in terms of pointing out the fact that states possess a formal sovereignty, and that only recognized legitimate state representatives can agree to give up or to "team up" the sovereignty. The reason why they have to agree to do that is a question that could be answered by looking at the limitations that the governments face in their governing.

\section{Theoretical and Practical Aspects of European Integration Policies}

In the Republic of Macedonia there is almost no professional literature or research that deals with the theoretical and practical perspectives of the policies of European Integration and there is especially a lack of it in terms of the relation of these policies towards the Republic of Macedonia. Due to all this as well as due to the importance of these policies and the theories that represent their basis, with the goal to come to new insights with these questions that have not been researched in our place so far.

- Our assumptions are the following:

- In the drafting of EU integration policies, the key influencing factors are:

- $\quad$ The number of aspiring candidates, how large they are, their geographic proximity to the Union at a particular period.

- The readiness of the aspiring countries for membership at the EU.

- $\quad$ EU's capacity for accepting new members.

- The interests of the existing member states.

The policies of conditioning are applicable to aspiring countries that will be net beneficiaries of the European Union and for which the fulfillment of the political conditions is not assumed beforehand.

The conditions for accession as key elements of the conditioning policies are becoming more and more difficult due to the following reasons:

The more extensive reforms which the state- subject of policies of conditioning should apply until the moment of accession.

- The lack of institutional and economic capacities of the Union for accession of new members, out of which the prolongation of the mandatory time for absorption of new members results.

The success of the policies for integration depends on:

The balance of its encouraging and punitive elements

The capacities of the aspiring country to create its national policies in order to be able to fulfill the membership criteria.

The development of dialogue and communication action could intensify the process of convergence between the aspiring countries and the Union, so that they maximise the positive implications of the policies of conditioning of the Union and minimize the negative ones.

\footnotetext{
${ }^{1}$ Hoffman, S.(1966) Obstinate or obsolete? 'The fate of the nation state and the case of Western Europe',Daedalus, vol.95, p.892-908

2 Chou Ta-kuan, The Custon of Cambodia, Bangkok: The Siam Society, 1993
} 


\section{Effective and Efficient Implementation in the Context of Integrative Processes}

In the context of integration there is one aspect of policy implementation that stands out- the imposed costs on partner countries from the national implementing measures. There are two types of relevant costs here: those that are caused by direct expiration (ex. loose inspection on safety of imported food) and the extra costs for harmonization that are imposed on the products and firms of the partner countries when they enter the national market.

Trade happens because the economies differ. Sometimes it pays off to stress the economic, technologic and regulatory differences. But open economies also gain from the fact that they do not differ drastically from their partners.

If the essence of integration, in this context, is to see the problem via "collective eyes" and "overall interests" of all partner countries; afterwards, the effective implementation of policy requires to rely on a transparent and well understood general standards and procedures; as well as on avoidance of using too complex and idiosyncratic standards and procedures.

An implication for candidate-countries is that they should strive for open and simple procedures, and perhaps copy good practices of member-states.

A question that is raised by the civil servants of the candidate-countries is how detailed should the implementation measures be? The sole question reveals that they understand that the task of implementing of the acquis is not merely copying of the directive provisions in the national law but also implementing them.

Why does the capacity to implement the acquis depends a lot on the quality of the incorporation of provisions into national law?

The amount of details that need to be included in the implementation measures depend primarily on two factors:

(a) the level of discretion in decision making that has been given to the competent organ for implementation, and

(b) the level up to which individuals and companies can take action of evasion in order to avoid harmonization. The bigger the level of discretion of decision making of the organ, the more general the implementation measures can be, and vice versa.

\section{How to Build Capacities for Efficient and Trustworthy Implementation of Eu Rules}

The countries that applied for membership in the EU are currently preoccupied with the big task of accepting and implementing the laws, policies and practices of the EU, otherwise known as 'acquis communautaire'. Even though the implementation of acquis is mainly understood as a technical issue and for now receives no significant meaning in the public, one of the goals is to explain the reason behind the large possibility that in the following twelve months, as the time toward the end of negotiation between the EU and leading candidate- countries approaches, this issue will become more relevant.

The need for trustworthy duties lies in the essence of integration, in whatever form that may be. It will be easier for the candidate-countries that demonstrate trustworthy duties towards the EU in terms of implementation of EU rules, if the task of implementing EU integration rules is given by institutions that are authorized and safe enough, independent in terms of deciding and which are subject to specific duties.

The fulfillment of whatever task requires three indispensble conditions: knowledge , skills and will (stimulating measures).

\section{Conclusion}

The question between inter-governmentalism and multi-levelled governance is the last phase of a long-lasting debate related with the dynamics of European Integration, even though in the framework of its current manifestation it looks more like a question of the phenomenon of the European Union more than of the process of integration.

The goal of this research paper is to go back to the original questions and it's an attempt to identify the dynamics of the integration, such as the transfer of political competencies from a national to a supranational level. This question inevitably focuses the attention on the stance of states, because the governments of the states will have to agree on the transfer of the competencies. 
Hoffman and Moravcsik are right when they state that states possess a formal sovereignty, and that only recognized legitimate representatives of states could agree to transmit or to "join" that sovereignty. Starting from a European level: the neo-functionalists identified processes of enlargement that formed on an internal integration dynamic. They claimed that after the first steps were taken in the process of integration, inevitably, other steps will follow, since in modern, independent sector economies, the integration in one sector, itself will generate deviations in other sectors as well which could be solved with additional integrative steps, or to withdraw from the already achieved level of integration.

\section{References}

[1] Hoffman, S.(1966) Obstinate or obsolete? 'The fate of the nation state and the case of Western Europe',Daedalus, vol.95.

[2] G. Marks, 'Structural Policy and Multi-level Governance in the EC, in A. Cafruny and G. Rosenthal (eds.), The State of the European Community, Volume 2: The Maastricht Debates and Beyond (Harlow: Longman, and Boulder, Co: Lynne Reiner, 1993).

[3] G. Marks, L. Hooghe, and K. Blank, 'European Integration since the 1980s: State-Centric Versus Multi-Level Governance', paper presented at the American Political Science Association Meeting, Chicago, August 31September3, 1995.

[4] Moravcsik, A. (1993) 'Preferences and power in the European Community: a liberal intergovermentalist approach', Journal of Common Market Studies, vol.31, no.4.

[5] Мехмеди, Сузана. „Европска интеграција во теорија и практика,, Универзитет на Југоисточна Европа Тетово, магистерска теза, 2009 